Mеталлофиз. новейшие технол. / Metallofiz. Noveishie Tekhnol. (C) 2014 ИМФ (Институт металлофизики 2014 , т. 36, № 2, сс. 189-193

Оттиски доступны непосредственно от издателя

им. Г. В. Курдюмова НАН Украины)

Фотокопирование разрешено только

Напечатано в Украине.

в соответствии с лицензией

PACS numbers: 61.72.Bb, 61.72.Cc, 61.72.Dd, 61.72.Hh, 66.30.Dn

\title{
Magnetic-Field-Stimulated Modification of Surface Charge and Defect Content in Silicon for Solar Energy Storage
}

V. A. Makara, L. P. Steblenko, O. A. Korotchenkov, A. B. Nadtochiy, D. V. Kalinichenko, A. M. Kuryliuk, Yu. L. Kobzar, and O. M. Krit*

Physical Department, Taras Shevchenko National University of Kyiv, 64/13 Volodymyrska Str., 01601 Kyiv, Ukraine

"Scientific Research Centre 'Physicochemical Materials', Taras Shevchenko National University of Kyiv and N.A.S. of Ukraine, 01033 Kyiv, Ukraine

The effect of a weak static magnetic field on the structure and charge state of silicon for solar energy storage is investigated. As found, the magnetic-fieldstimulated changes in the defect-impurity state and surface potential are reversible.

В роботі досліджено вплив слабкого сталого магнітного поля на структуру та зарядовий стан кремнію для сонячної енергетики. Виявлено, що магнітостимульовані зміни дефектно-домішкового стану та поверхневого потенціалу мають зворотній характер.

В работе исследуется влияние слабого постоянного магнитного поля на структуру и зарядовое состояние кремния для солнечной энергетики. Обнаружено, что магнитостимулированные изменения дефектно-примесного состояния и поверхностного потенциала носят обратимый характер.

Key words: 'solar' silicon, impurities, magnetic field, surface potential, carrier recombination time.

(Received April 23, 2013)

\section{INTRODUCTION}

Despite considerable efforts, it has still much to be done in studying of magneto-stimulated effects on structure and physical characteristics of solar silicon. This research field is of remarkable importance be- 
cause numerous devices made of solar silicon are frequently used in hazardous operation conditions, including radiation and electromagnetic fields. Although the response of the devices on the electrical component of the electromagnetic field is well addressed, little is known about the effect of the magnetic component.

Recently, the effect of magnetic fields, including weak fields (induction $B \leq 1 \mathrm{~T}$ ), on the physical characteristics of low-magnetic materials with various types of chemical bonds [1-12] has been actively studied. The share of such scientific studies of covalent crystals, in particular, silicon crystals, is rather small. Magnetically sensitive phenomena have not been studied at all on solar-grade silicon crystals. The fact that problems concerning the effect of magnetic fields on the properties and real structure of 'nonmagnetic' solar-grade silicon crystals are still studied insufficiently makes their consideration appropriate and topical.

In our previous work [13], the influence of the static magnetic field with $B=0.17 \mathrm{~T}$ on the decay kinetics of the photoconductivity in solar silicon crystals has been reported. The particular attention has been given to the reversal effect of electro-physical characteristics in solar silicon with time after the magnetic field is switched off.

In order to explain the observed features [13], the hypothesis has been suggested that the changes in the decay kinetics are caused by adsorbed and gettered by the magnetically activated surface charged impurity centres. It is a goal of this work to verify this hypothesis experimentally.

\section{EXPERIMENTAL}

Experiments were performed on p-type solar grade Czochralski-grown $\mathrm{Si}$, boron doped to the resistivity of $5 \mathrm{Ohm} \cdot \mathrm{cm}$. Magnetic treatment was performed by placing Si samples into the static magnetic field $H=0.17$ T during a time interval $t$.

The impurity content both of the control samples placed out of the magnetic field and the samples subjected to the magnetic field treatment is carried out using X-ray spectral analysis, which combines an $\mathrm{X}$-ray analyser and a scanning (transmission) electron microscopy apparatus. Surface photovoltage (SPV) transients are measured in the capacitor arrangement [5], and details of our setup are given elsewhere $[14,15]$.

The scanning SPV apparatus based on the AC-SPV technique and utilizing a 'flying spot' arrangement is used for obtaining SPV decays and spatially-resolved SPV maps. The 7-mW light-emitting diode (LED) with light peak at about $650 \mathrm{~nm}$ is used as the excitation source. This technique is capable of providing wafer maps of both the photovoltage magnitude and carrier lifetime with a $100-\mu \mathrm{m}$ spatial resolu- 
tion.

\section{RESULTS AND DISCUSSION}

Figure 1 compares the SPV surface distributions taken in one of our samples before $(a)$ and after $(b)$ magnetic treatment. It is seen that the treatment enhances the SPV signal remarkably (up to two times) making its distribution over the sample surface much more uniform. The uniformity and the total area of the enhanced SPV are found to increase with increasing the treatment time $t$. It is most likely that both the signal and the area increase are caused by impurity adsorption and gettering effects occurring in the subsurface region of the sample in the presence of the magnetic field. These would affect the surface charge altering the surface band bending, which in turn affects SPV.

Therefore, it should be noted that dopants could be coerced into the subsurface redistribution by applying external magnetic fields thereby affecting the surface charge. It is also important to note that the broadened SPV distribution given by $(b)$ in Figure relaxes to its nearly initial shape (cf. (a) in Figure) well after the magnetic field is switched off, indicating a reversible redistribution of dopants in magnetic fields.

Application of the X-ray spectroscopy technique shows that the carbon (C) atom concentration exhibits up to 4.8-times increase in the subsurface region of the sample with a depth of about $2 \mu \mathrm{m}$ due to magnetic treatments. The concomitant increase in the oxygen $(\mathrm{O})$ concentration is about 1.6 times, and these enhancements are accompanied by changes in the Si matrix content.

We believe that the above observations can be explained by the mag-
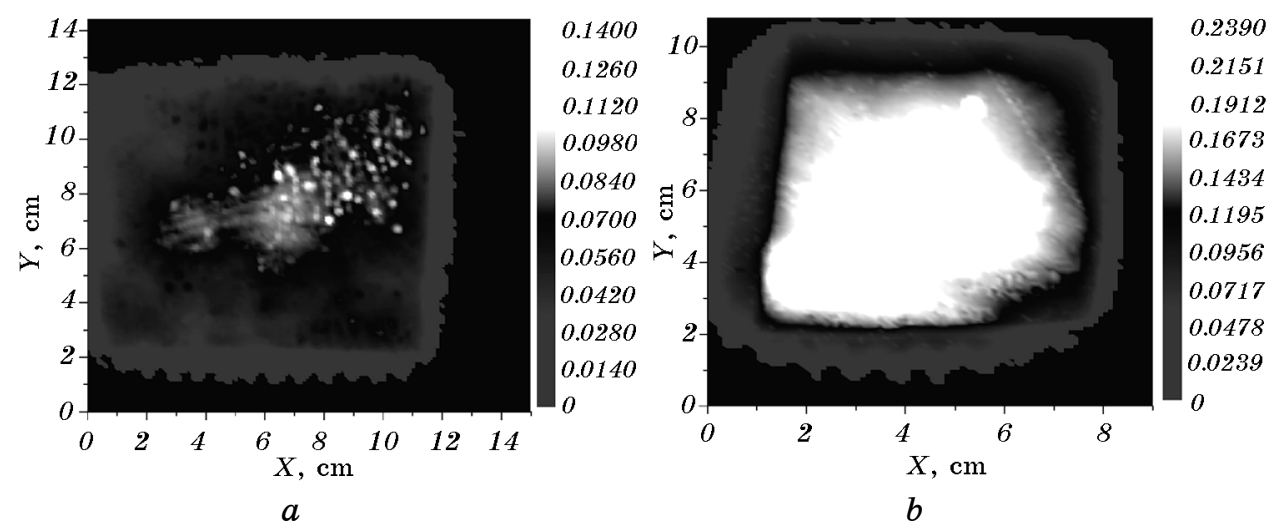

Fig. 1. Surface distribution of the SPV signal in the control $(a)$ and magnetically treated $(b)$ samples of solar $\mathrm{Si}$. The treatment time is $t=7$ days in $(b)$. 
netic field stimulated inter-defect interaction of carbon with oxygen and silicon atoms giving rise to the $\mathrm{Si}-\mathrm{C}-\mathrm{O}$ defect complexes, which have been found to be electrically active and affect the surface charge [16].

Measurement of the SPV decays allows one to relate directly the observed decay time to the recombination time of photoexcited carriers through the barriers generated by charged impurities and defect complexes. It is found that the observed broadening of the SPV distribution is in a good agreement with enhanced times $\tau_{\text {rec }}$ pertinent to the carrier recombination through the barriers. The value of $\tau_{\text {rec }}$ shows 2 to 2.5-times increase in the magnetic field. Again, keeping the sample out of field for a prolonged time ceases the $\tau_{\text {rec }}$ increase to exist, similar to the above relaxation of the SPV signal and its surface distribution.

This in turn illustrates that the charge state of the centres responsible for SPV is unstable. It is likely that, with a time span after the magnetic field is switched off, charged centres become involved into the magnetic field stimulated inter-defect reactions, for example, with the magnetic field induced surface-adsorbed oxygen, carbon atoms and hydroxyl groups. Therefore, the charge of the latter defects is neutralized.

This suggestion is confirmed by studying the $\mathrm{O}$ and $\mathrm{C}$ content in the subsurface region of our samples, which is done using the X-ray spectroscopy technique. It is found that, in $\mathbf{1 4}$ days after the magnetic treatment, the oxygen content is $\mathbf{1 . 4}$ times greater than that observed before the application of the magnetic field. This fact implies that the oxygen adsorption gradually increases with time. The carbon content increases even more, exhibiting 5 -times increase in 14 days after the magnetic treatment. Meanwhile, in 65 days after the treatment, the $\mathrm{O}$ and $\mathrm{C}$ content starts to decrease, finally showing the values observed before the application of the magnetic field.

Therefore, the magnetic treatment of solar silicon causes a longlived evolution of the doping content in the subsurface region, which is accompanied by modifying of the surface charge.

\section{REFERENCES}

1. V. I. Al'shits, E. V. Darinskaya, T. M. Perekalina, and A. A. Urusovskaya, Sov. Phys. Solid State, 29: 265 (1987).

2. Ya. B. Zel'dovich, A. L. Buchachenko, and E. L. Frankevich, Sov. Phys. Uspekhi, 31: 385 (1988).

3. V. M. Maslovskii and S. N. Postnikov, Proceedings of the 4th Scientific Technical Seminar on Processing by Pulse Magnetic Field (Methods and Technology) (Gorky, Sofia: 1989), p. 5.

4. V. N. Buzykin, O. I. Datsko, and S. N. Postnikov, Elektron.Obrab. Mater., 2: 16 (1993) (in Russian).

5. M. N. Levin and B. A. Zon, Zh. Exp. Teor. Fiz., 84, 760 (1997) (in Russian).

6. M. N. Levin, G. V. Semenova, and T. P. Sushkova, Phys. Solid State, 45: 639 
(2003).

7. M. N. Levin, A. V. Tatarintsev, O. A. Kostsov, and A. M. Kostsov, Tech. Phys., 48: 1304 (2003).

8. Yu. I. Golovin, Phys. Solid State, 46: 79 (2004).

9. R. B. Morgunov, Phys. Uspekhi, 47: 125 (2004).

10. A. L. Buchachenko, JETP, 105: 593 (2007).

11. V. A. Makara, L. P. Steblenko, A. M. Korduban, O. V. Matveeva, A. N. Kuryliuk, S. N. Naumenko, Yu. L. Kolchenko, and G. V. Vesna, Materials and Structures of Modern Electronics (Minsk: 2006), p. 189 (in Russian).

12. V. A. Makara, M. A. Vasiliev, L. P. Steblenko, O. V. Koplak, A. N. Kuryliuk, Yu. L. Kobzar, and S. N. Naumenko, Semiconductors, 42: 1044 (2008).

13. V. A. Makara, O. A. Korotchenkov, L. P. Steblenko, A. A. Podolyan, and D. V. Kalinichenko, Semiconductors, 47, No. 5: 652 (2013).

14. A. Podolian, V. Kozachenko, A. Nadtochiy, N. Borovoy, and O. Korotchenkov, J.Appl. Phys., 107: 093706 (2010).

15. A. B. Nadtochy, O. A. Korotchenkov, and V. V. Kuryliuk, Zhurnal Tekhnicheskoi Fiziki, 83, No. 3: 84 (2013) (in Russian).

16. V.S. Vavilov, Defects in Silicon and on Its Surface (Moscow: Nauka: 1990) (in Russian). 